\title{
Reducing Hydro-Meteorological Risk by Nature-Based Solutions: What Do We Know about People's Perceptions?
}

\author{
Sungju Han ${ }^{1,2, *(\mathbb{C})}$ and Christian Kuhlicke ${ }^{1,2,3}$ \\ 1 Department of Urban and Environmental Sociology, UFZ-Helmholtz Centre for Environmental Research, \\ Permoserstraße 15, 04318 Leipzig, Germany; Christian.Kuhlicke@ufz.de \\ 2 Institute for Environmental Sciences and Geography, University of Potsdam, 14468 Potsdam-Golm, Germany \\ 3 German Centre for Integrative Biodiversity Research (iDiv) Halle-Jena-Leipzig, Deutscher Platz 5e, \\ 04103 Leipzig, Germany \\ * Correspondence: sungju.han@ufz.de
}

Received: 16 October 2019; Accepted: 5 December 2019; Published: 10 December 2019

\begin{abstract}
Nature-based solutions (NBS) have recently received attention due to their potential ability to sustainably reduce hydro-meteorological risks, providing co-benefits for both ecosystems and affected people. Therefore, pioneering research has dedicated efforts to optimize the design of NBS, to evaluate their wider co-benefits and to understand promoting and/or hampering governance conditions for the uptake of NBS. In this article, we aim to complement this research by conducting a comprehensive literature review of factors shaping people's perceptions of NBS as a means to reduce hydro-meteorological risks. Based on 102 studies, we identified six topics shaping the current discussion in this field of research: (1) valuation of the co-benefits (including those related to ecosystems and society); (2) evaluation of risk reduction efficacy; (3) stakeholder participation; (4) socio-economic and location-specific conditions; (5) environmental attitude, and (6) uncertainty. Our analysis reveals that concerned empirical insights are diverse and even contradictory, they vary in the depth of the insights generated and are often not comparable for a lack of a sound theoretical-methodological grounding. We, therefore, propose a conceptual model outlining avenues for future research by indicating potential inter-linkages between constructs underlying perceptions of NBS to hydro-meteorological risks.
\end{abstract}

Keywords: disaster risk reduction; climate change adaptation; river restoration; green infrastructure; ecosystem services; acceptability; attitudes; co-benefits; preferences; participation

\section{Introduction}

An increase in natural hazards caused by meteorological and climate events such as floods, landslides, and hurricanes has been observed worldwide in recent decades [1]. When these hazards are coupled with societal vulnerabilities [2,3], it creates a higher chance of disasters, which can cause not only serious economic loss but also loss of lives [4]. Moreover, the likelihood of these hazards could become even higher in the future because of changes in precipitation and temperature patterns associated with ongoing global climate change $[5,6]$. Next to climate change, alterations of land-use also play a decisive role in potentially increasing hydro-meteorological risk [7-9]. Rural areas have been converted into urban landscapes, resulting in more deforested or drained areas vulnerable to erosion $[10,11]$ as well as an increased number of assets, infrastructure, and people exposed to hydro-meteorological hazards [12-14].

In response to this phenomenon, nature-based solutions (NBS) have recently received considerable attention $[15,16]$. They are positioned as an alternative to conventional technical solutions that have so 
far dominated the management of hydro-metrological risks [17]. In contrast to traditional management measures, NBS are inspired by or copied from natural processes. NBS help to address multiple societal challenges and pursue more than one single objective (i.e., reduce hydro-meteorological risks); rather, they aim to generate multiple co-benefits for both ecosystems and humans $[18,19]$. Therefore, great efforts are currently being undertaken to establish pioneering projects that aim to design and implement NBS as well as systematically evaluate the wider co-benefits of NBS. Although some expected co-benefits are not tangible [20] and need long-term observation strategies to evaluate them [21], it is anticipated that the documentation of the wider effects of NBS will help stakeholders to better understand the potential positive impacts of NBS and eventually lead to increased uptake [22]. In addition to the evaluation of co-benefits, there is also an emerging debate focusing on actors, institutions, and their interactions in order to identify governance conditions that support or hinder NBS [23-25].

In this article, we aim to complement recent research that evaluates the co-benefits of NBS and the wider governance context. Although the importance of NBS and their effective implementation has been recognized [26-28], a comprehensive analysis of factors shaping perceptions of NBS as a means to reduce hydro-meteorological risks is still lacking. It is generally acknowledged that negative perceptions of NBS can be a decisive barrier to the uptake of NBS. Decision-makers might be uncertain with respect to the effects of NBS as well as with respect to procedural aspects related to their planning, implementation, and maintenance [28]. Similarly, perceptions of NBS can be shaped by cognitive barriers, such as unawareness or fear, discouraging stakeholders from considering the realization of NBS [29]. Moreover, the few existing studies that focus on NBS as a means to reduce hydro-meteorological risks highlight conflicting views. On the one hand, some studies imply that NBS are perceived positively as they not only help to reduce risks, but can also result in co-benefits [30,31]. On the other hand, studies suggest that exposed residents prefer technical solutions over NBS as the latter are perceived as less effective in reducing risks [32,33].

In addition, we aim to advance the discussion on perceptions of hydro-meteorological risks. Within the social sciences, the term 'risk perception' has a long tradition [34]. It refers to the process of collecting, selecting, and interpreting signals about uncertain impacts of events, activities, or technologies $[35,36]$. In recent years, a behavioral turn has occurred in this field of research, focusing on perceptions of risks and factors shaping individual adaptive behavior [37]. Relevant factors that have been identified include: experience of flood damage [38-40], personal risk perception [38,41], fear of flooding in the future [42,43], and coping appraisal (including self-efficacy and response/outcome efficacy) [38,41]. Some studies have also identified that individual adaptive behavior is positively influenced by perceived social norms [44,45], local connectedness [46] and perceived incentives for adaptive behavior [45]. What is lacking in this strand of research is how perceptions of measures to reduce future risks interact with both perceptions of risk as well as adaptive behavior. By means of this literature review, we aim to lay the basis for future research endeavors that tackle the above-mentioned relationships.

Against this background, this review paper aims to provide a systematic analysis of state-of-the-art research considering people's perceptions of NBS in the context of hydro-meteorological risks. By perceiving NBS as a means to reduce hydro-meteorological risks, we refer predominantly to how people perceive the co-benefits of NBS as well as the perceived efficacy of NBS to reduce risks.

The paper is structured as follows: Section 2 provides an overview of key terminology including NBS and relevant neighboring concepts, Section 3 lays out the methodology underlying the review process, Section 4 presents the main findings, Section 5 follows with a discussion, and Section 6 concludes with some overarching remarks.

\section{Key Definitions and NBS as an Overarching Concept}

In this section, we provide a short synoptic overview of NBS and their differences and similarities to related concepts, such as ecosystem-based adaptation/risk reduction or green infrastructure. 
Incorporating neighboring terms is relevant, not only because NBS is a relatively new concept but also because it is vaguely defined [47]; this section also helps to further specify the definition of NBS underlying this literature review (see Section 3).

The scope of NBS, and how they differ from similar concepts, is a matter of ongoing debate [23,48]. Nesshover et al. [23], for instance, have identified six neighboring concepts: (1) ecological engineering/catchment systems engineering, (2) green/blue infrastructure, (3) ecosystem approach, (4) ecosystem-based adaptation/mitigation, (5) ecosystem service approach/framework, and (6) natural capital. Each of these concepts is based on different definitions (also for each of the terms), pursues different objectives and can have potentially different relations to the NBS concept. In our view, there are two different viewpoints on NBS that can be identified: While some argue that NBS should be understood as an inclusive umbrella term that spans various neighboring concepts, others argue that NBS is a concept that is distinct from other established concepts. To further illustrate both views, a close look at two common definitions of NBS is helpful.

Since 2013, the European Commission (EC) has conceptualized NBS within the spectrum of ecosystem-based approaches 'as a way to address societal challenges with solutions that are inspired and supported by nature, which are cost-effective, simultaneously provide environmental, social, and economic benefits and help build resilience.' [49]. The International Union for Conversation of Nature (IUCN) provides a similar, but slightly different definition: NBS are understood as "actions to protect, sustainably manage and restore natural and modified ecosystems that address societal challenges effectively and adaptively, simultaneously providing human well-being and biodiversity benefits" [50]. Both definitions are directed towards addressing societal challenges (e.g., risk reduction) and highlight the decisive role of ecosystem processes that are framed as a means to provide multiple co-benefits to ecosystems and society. The IUCN definition, however, clearly features the relevance of protecting, sustainably managing, and ideally restoring ecosystems that have been modified by anthropogenic use. On the contrary, the EU definition is less strict with respect to the protection/restoration of ecosystems; it rather highlights how nature might support addressing societal challenges [25].

Applying both definitions to the subject of this literature review, differences in the means of reducing hydro-meteorological risks become apparent. Whereas conventional measures to reduce hydro-meteorological risks frame 'nature' as an external entity that triggers hazards, both definitions highlight the importance of re-introducing nature as a solution to benefit both ecosystem and humans [18,51]. In this respect, both definitions focus on NBS to tackle the societal challenge of reducing risks by fostering resilience through consciously using the capacity of nature $[25,33,52]$. However, these definitions propose different means to reduce risks. On the one hand, the EC definition implies that 'ecosystem-based' solutions are not the sole way of reducing risks-NBS can also include engineered hybrid solutions, meaning a mix of green and gray solutions $[53,54]$. The stance of the EC also clearly differs from that of the IUCN in terms of cost-effectiveness of the solution: the EC places the importance of cost-effectiveness at the same level as the multiple benefits in diverse systems and resilience that NBS can bring. On the other hand, the IUCN definition has a different emphasis: if NBS are utilized to reduce hydro-meteorological risks, they should also protect and restore affected ecosystems. In this regard, the IUCN definition has a clear focus on protecting or restoring ecosystems, such as river/ecological restoration and ecological engineering.

Likewise, various allegedly neighboring terms have shown some similarities and differences in comparison with the definitions provided by EC and IUCN. Table 1 illustrates some of the most relevant neighboring terms including ecosystem-based adaptation, river restoration/ecological engineering, and green infrastructure that are of relevance with respect to reducing hydro-meteorological risks. While the concept of ecosystem-based adaptation is quite similar to NBS, as it also points towards promoting multiple co-benefits apart from environmental benefits, its scope is more limited compared to that of NBS as it focuses primarily on reducing the consequences of climate change. Concepts related to river restoration/ecological engineering emphasize the relevance of re-naturalizing ecological elements so that riverine ecosystems develop the capacity to regenerate themselves. In that sense they 
are close to the IUCN definition. However, publications for restoration have increased in past decades, not only focusing on classical ecological theories but also rendering 'nature' as an objective for human use [55], embracing utilitarian concerns that align more closely with the EC definition [48]. In other words, restoration works should meet the needs of humans and, to do so, the delivery of the ecosystem should be maximized. Last, green infrastructure is a concept that originally emerged in urban contexts, whereas it meanwhile has also been adopted in rural contexts [56]. A major difference lies in the focus provided by the definition to solve a pressing societal problem: Whereas NBS emphasize a variety of actions to be taken, green infrastructure points towards solutions that can be provided by 'infrastructure'.

In the light of the previous discussion and being aware of similarities, differences, and the underlying vagueness in NBS concepts $[23,47,50]$, we are not pursuing a narrow definition of NBS [48]. Rather, our analysis is inclusive of various neighboring terms (see Section 3). In line with the definition provided by the EC, the solutions should be clearly directed towards a societal challenge (in this case disaster risk reduction and climate change adaptation), the means to achieve this objective should be inspired and supported by ecosystems and they should provide wider co-benefits for society and/or ecosystems. 
Table 1. Interlinkages of the related concepts of nature-based solutions (NBS) in hydro-meteorological contexts.

\begin{tabular}{|c|c|c|c|c|}
\hline \multirow[b]{2}{*}{ Concept (Main) } & \multirow{2}{*}{$\begin{array}{c}\text { Ecosystem-Based Approach } \\
\text {-Ecosystem-Based Adaptation }\end{array}$} & \multicolumn{2}{|c|}{ Restoration Technology/Engineering Approach } & \multirow{2}{*}{$\begin{array}{c}\text { Infrastructure-Related Approach } \\
\text {-Green Infrastructure }\end{array}$} \\
\hline & & -River Restoration & -Ecological Engineering & \\
\hline Other concepts & $\begin{array}{c}\text {-Ecosystem Services } \\
\text {-Ecosystem Disaster Risk Reduction }\end{array}$ & $\begin{array}{c}\text {-Ecological Restoration } \\
\text {-Ecosystem-service Restoration }\end{array}$ & -Hybrid Engineering & $\begin{array}{l}\text {-Blue-Green Infrastructure } \\
\text {-Natural Infrastructure }\end{array}$ \\
\hline Definition & $\begin{array}{l}\text { 'use biodiversity and ecosystem } \\
\text { services as part of an overall } \\
\text { adaptation strategy to help people } \\
\text { to adapt to the adverse effects of } \\
\text { climate change.' [57] }\end{array}$ & $\begin{array}{l}\text { 're-establishment of natural } \\
\text { physical processes (e.g., variation of } \\
\text { flow and sediment movement), } \\
\text { features (e.g., sediment sizes and } \\
\text { river shape) and physical habitats } \\
\text { of a river system (including } \\
\text { submerged, bank and floodplain } \\
\text { areas).... it promotes the idea of } \\
\text { encouraging natural processes to } \\
\text { create characteristic, self-sustaining, } \\
\text { dynamic physical habitat that } \\
\text { induces biological recovery and } \\
\text { restores the benefits humans rely } \\
\text { on.' [58] }\end{array}$ & $\begin{array}{l}\text { 'the design of sustainable ecosystems } \\
\text { that integrate human society with its } \\
\text { natural environment for the benefit of } \\
\text { both' [59] } \\
\text { 'actions using and/or acting for nature' } \\
\text { [60] '...can stand alone, but can also } \\
\text { be incorporated into hybrid } \\
\text { engineering solutions, where } \\
\text { ecosystems are utilized alongside } \\
\text { engineered defenses.' [53] }\end{array}$ & $\begin{array}{l}\text { 'an interconnected network of natural } \\
\text { areas and other open spaces that } \\
\text { conserves natural ecosystem values } \\
\text { and functions, sustains clean air and } \\
\text { water, and provides a wide array of } \\
\text { benefits to people and wildlife.' [61] } \\
\text { '...is a strategically planned network } \\
\text { of natural and semi-natural areas } \\
\text { with other environmental features } \\
\text { designed and managed to deliver a } \\
\text { wide range of ecosystem services. } \\
\text { It incorporates green spaces (or blue } \\
\text { if aquatic ecosystems are concerned) } \\
\text { and other physical features in } \\
\text { terrestrial (including coastal) and } \\
\text { marine areas. On land, green } \\
\text { infrastructure is present in rural and } \\
\text { urban settings.' [56] }\end{array}$ \\
\hline Focus & $\begin{array}{l}\text { Benefits that humans derive from } \\
\text { biodiversity and ecosystem services, } \\
\text { focus on tackling with climate } \\
\text { change [23] }\end{array}$ & Ecosystem self-design and self-organ & ization [62] & $\begin{array}{l}\text { Connectivity, multifunctionality, and } \\
\text { smart conservation [63] }\end{array}$ \\
\hline
\end{tabular}




\section{Methods}

We conducted a systematic literature review using the Web of Science database by following the PRISMA guidelines. Web of Science provides an advanced research query tool that guarantees effective and proper coverage [64]. We used a structured query with keywords from three categories to extract the literature from the aforementioned database. This included NBS and relevant neighboring terms, different hydro-meteorological hazards as well as key themes we considered as relevant for a better understanding of how people perceive NBS. We based our search in the Web of Science on the Topic Search, which includes title, abstract, author keywords, and Keywords Plus (assigned by Web of Science). Table 2 summarizes the searched terms and an overview of how we conducted the search.

Table 2. Keywords for the literature survey.

\begin{tabular}{|c|c|c|}
\hline NBS and Related Concepts & Hydro-Meteorological Hazards & Key Themes \\
\hline $\begin{array}{ll}\text { - } & \text { Nature-based Solution } \\
\text { - } & \text { Ecosystem-based solution/management } \\
\text { - } & \text { /adaptation/mitigation/approach/framework } \\
\text { - } & \text { Catchmentogical engineering } \\
\text { - } & \text { Ecological Restoration } \\
\text { - } & \text { Green Infrastructure } \\
\text { - } & \text { Natural Infrastructure } \\
\text { - } & \text { Eco-hydrological solution/management } \\
\text { - } & \text { /adaptation/mitigation/engineering } \\
\text { - } & \text { Adaptation service } \\
\text { - } & \text { River Restoration } \\
\end{array}$ & $\begin{array}{ll}\text { - } & \text { Pluvial Risk/Hazard } \\
\text { - } & \text { Coastal Risk/Hazard } \\
\text { - } & \text { Meteorological Risk/Hazard } \\
\text { - } & \text { Hydrological Risk/Hazard } \\
\text { - } & \text { Flood Risk/Hazard } \\
\text { - } & \text { Climate Change Risk/Hazard } \\
\text { - } & \text { Disaster Risk/Hazard } \\
\text { - } & \text { Natural Risk/Hazard } \\
\text { - } & \text { Environmental Risk/Hazard }\end{array}$ & $\begin{array}{ll}\text { - } & \text { Perception } \\
\text { - } & \text { Awareness } \\
\text { - } & \text { Resilience } \\
\text { - } & \text { Participation } \\
\text { - } & \text { Stakeholder Involvement } \\
\text { - } & \text { Vulnernance } \\
\text { - } & \text { Trust } \\
\text { - } & \text { Planning } \\
\text { - } & \text { Policy } \\
\text { - } & \text { Acceptance } \\
\text { - } & \text { Cognition } \\
\text { - } & \text { Preference } \\
\end{array}$ \\
\hline \multicolumn{3}{|c|}{ Search Terms } \\
\hline 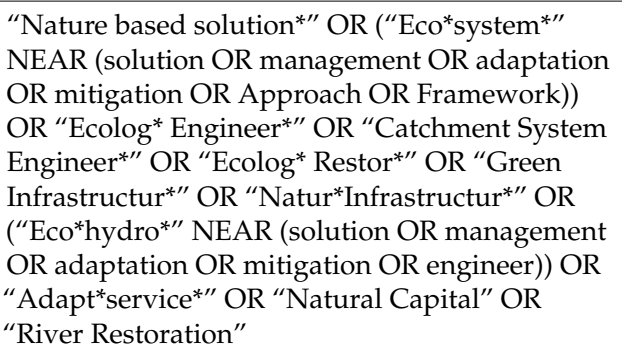 & $\begin{array}{l}\text { AND } \\
\text { (pluv* OR coast* OR *meteo* OR } \\
\text { hydro* OR flood* OR climate } \\
\text { Change OR disaster OR natural } \\
\text { OR environmental) AND (risk OR } \\
\text { hazard) }\end{array}$ & $\begin{array}{l}\text { AND } \\
\left(\text { perce }^{*}\right) \text { OR (aware*) OR } \\
\left(\text { resilien*) OR (participat }^{*}\right) \text { OR } \\
\text { (stakeholder involv*) OR } \\
\text { (governance) OR (vulnerab*) } \\
\text { OR (trust) OR (planning) OR } \\
\left.\text { (policy) OR (accept }{ }^{*}\right) \text { OR } \\
\left.\left({ }^{*} \text { cognit }^{*}\right) \text { OR (prefer }\right)\end{array}$ \\
\hline
\end{tabular}

The search elicited 1834 entries. All entries were scanned by having a closer look at the title, abstract, and keywords in order to exclude entries of no relevance for the aim of this study. We only considered papers that included at least one search term within each of three categories (i.e., neighboring terms, hydro-meteorological hazards, and key themes). Articles that did not focus on the reduction of hydro-meteorological risks, such as forest fire, landslide, volcanic risk, etc. were eliminated. After this screening process, 110 papers were left for full-text assessment for its eligibility. These 110 papers were fully read in order to identify papers that have no direct relation to the topic of this paper. Through this process, eight papers were excluded again, resulting in a final database of 102 papers.

With this database, we drew an overview which includes: the types of conceptual terms underlying the studies (e.g., NBS, green infrastructure, restoration, etc.); countries where the study was conducted (if the study has more than one site, all sites mentioned were counted); year of publication; type of analysis followed in each of the papers (e.g., review study, original empirical research), and key topics underlying the studies in order to better understand the factors shaping the perceptions of NBS as a means to reduce hydro-meteorological risks (see Section 4 for the results). During this step, it became apparent that the majority of papers $(N=71)$ were too generic and lacked methodological rigorousness in order to generate robust evidence on factors shaping perceptions of NBS as a means to reduce hydro-meteorological risks. In this regard, we decided to identify the papers that were based on a 
robust methodology and which presented empirical evidence in order to pursue an in-depth analysis. As a result, we chose 31 field studies for the in-depth analysis. The flow chart that shows the whole analytical reviewing process can be found in Figure 1.

The authors acknowledged the inherent limitations of the methodology. The online research of the peer-reviewed papers using keywords does not provide an exhaustive survey, lacking other essential documents such as gray literature or project reports. However, with the concise and detailed keywords, the authors tried to include the relevant articles as much as possible. To minimize such errors, the result was also double-checked by both authors to raise the credibility of the analysis. By doing so, this review provided readers insight into the scholarly work on the perceptions of NBS with a social science perspective.

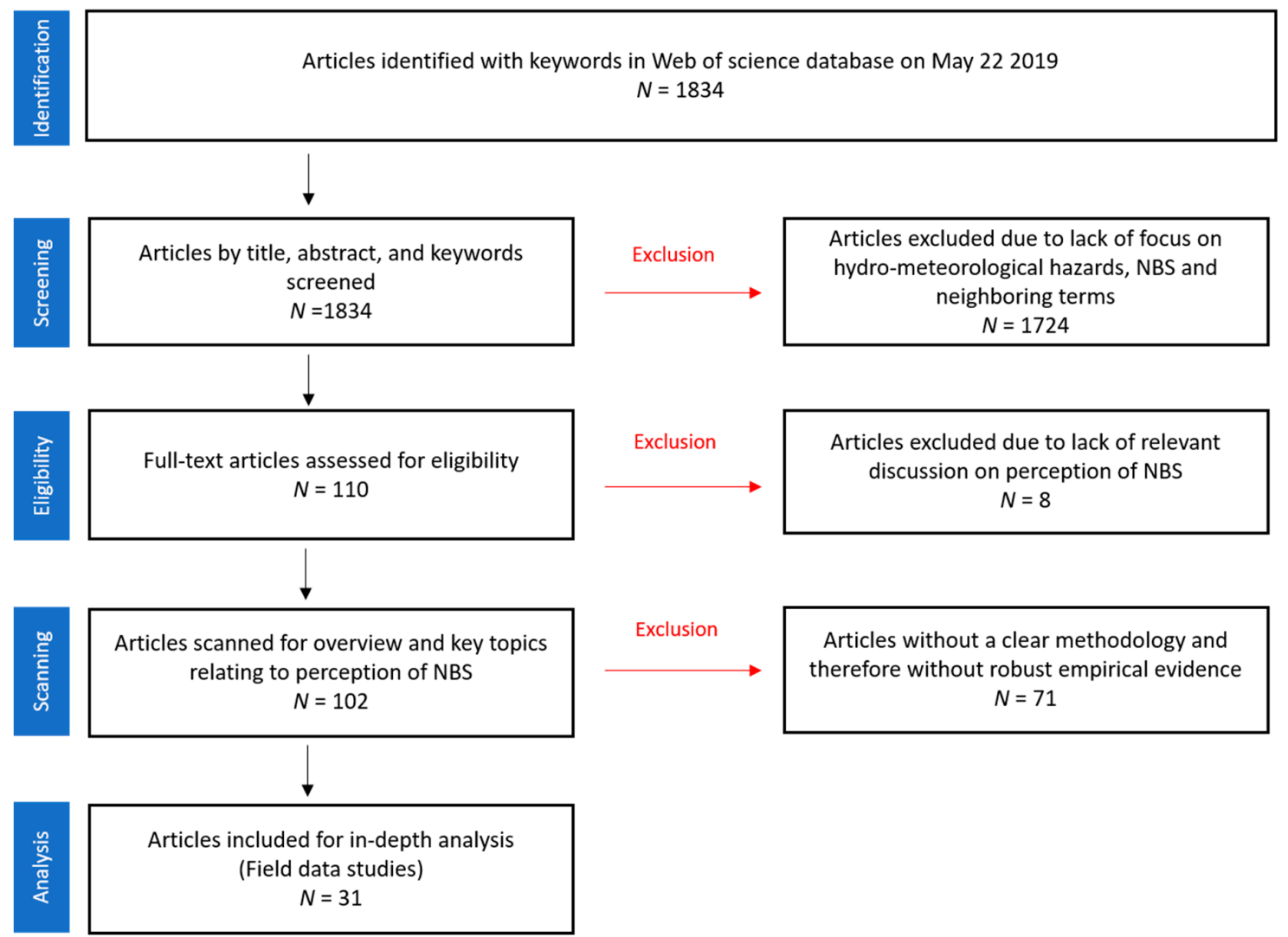

Figure 1. Flow chart of the underlying review process.

\section{Result}

In this section, we present the findings of the review as follows. First, the background information of 102 relevant articles is outlined, such as publication trends, usage of conceptual terms, and geographical location of papers. Second, we identify the core topics that construct perceptions of NBS in hydro-meteorological contexts. Last, the result of in-depth analysis investigating the evidence of the aforementioned topics in 31 field data studies is presented by each topic.

\subsection{Overview of the Relevant Articles}

All 102 papers were published between January 2000 and May 2019. Although papers focusing on 'ecosystem-based' and 'green infrastructure' were already being published in the 1980s and early 1990s $[65,66]$, they did not focus on the hazards and key topics relevant for this review. As Figure 2 indicates, the number of publications has increased over time. Not only has the absolute number of selected publications increased, but also the normalized value of numbers of the selected papers shows 
an increase in more recent years compared to the normalized value of papers with the topic of flood risk in general. The keywords for the general flood research included the topics we outlined in the 'hydro-meteorological hazard' column in Table 2. The escalation of normalized values in the selected publications indicates that the increase in the number of selected papers did not correlate with an overall increase in general flood risk research, but rather seemed to be related to a greater focus on NBS and neighboring concepts.

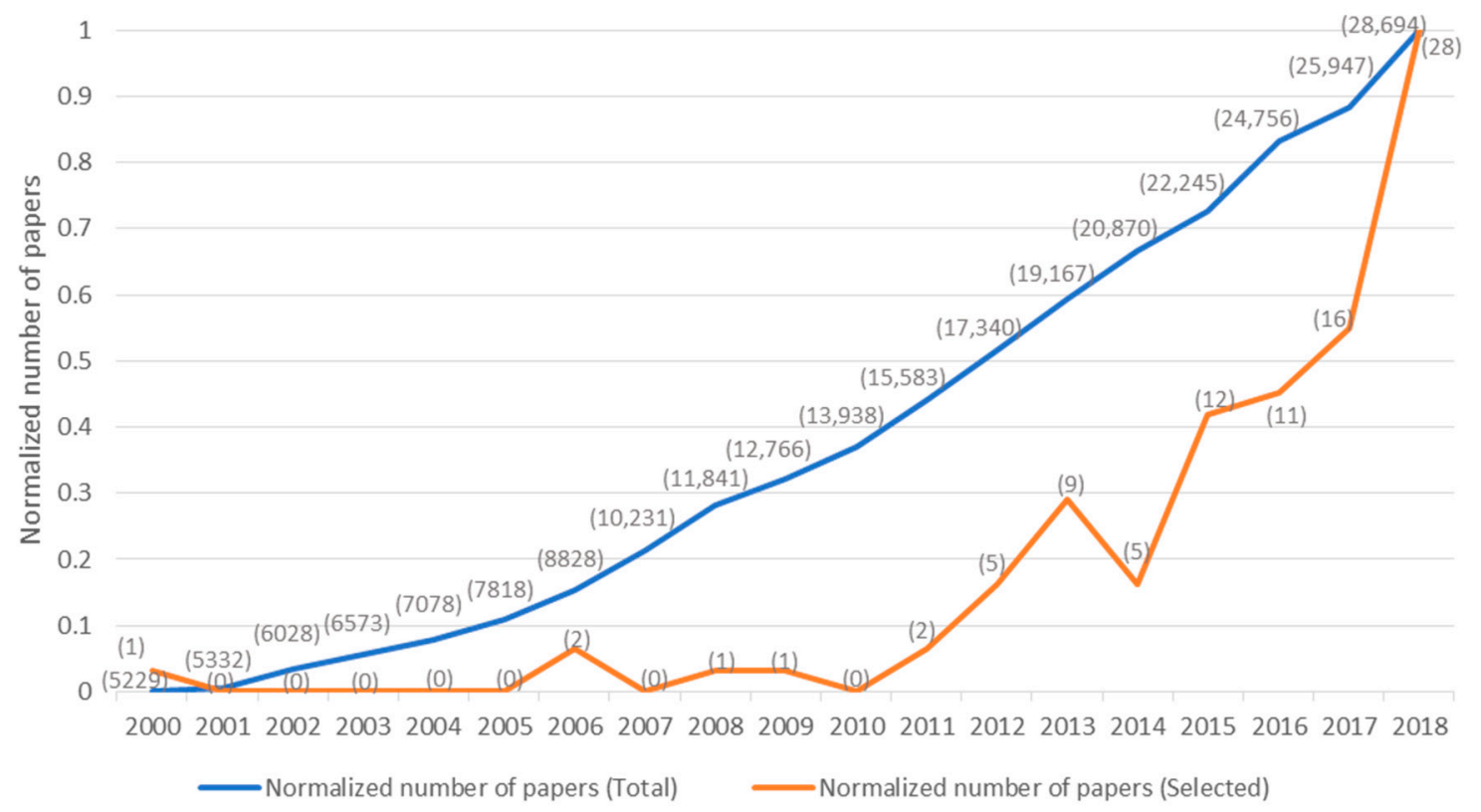

Figure 2. Normalized number of articles comparing the selected papers $(n=102)$ with all flood-related publications between 2000 and 2018 in Web of Science (see Table 2; hazard context).

In a next step, we classified whether the papers focused on NBS or neighboring concepts (Table 3). The broad concepts that represent the sum of sub-concepts are stated in bold. The term 'ecosystem-based' was most widely used in the papers we selected $(n=31,30 \%)$, followed by 'green infrastructure' $(n=24,24 \%)$ and 'restoration' $(n=21,21 \%)$. NBS was used in 14 papers $(14 \%)$, and noticeably all of them were published after 2016 reflecting the recent history of the term. Three papers used the term 'natural infrastructure' or 'nature-based infrastructure.' Besides, nine papers labeled as 'Etc.' adopted specific contextual terms such as hybrid engineering, multi-functional urban watercourses, de-culverting, etc. 
Table 3. The list of full concepts in broad conceptual categories.

\begin{tabular}{|c|c|c|}
\hline Concepts & Number of Papers & Percent \\
\hline Ecosystem-based & 31 & $30 \%$ \\
\hline Eco-Disaster Risk Reduction & 4 & $4 \%$ \\
\hline Ecosystem Approach & 1 & $1 \%$ \\
\hline Ecosystem Services & 4 & $4 \%$ \\
\hline Ecosystem-based Adaptation & 13 & $13 \%$ \\
\hline Ecosystem-based Approach & 1 & $1 \%$ \\
\hline Ecosystem-based DRR & 2 & $2 \%$ \\
\hline Ecosystem-based Management & 5 & $5 \%$ \\
\hline Ecosystem-based Solution & 1 & $1 \%$ \\
\hline Green Infrastructure & 24 & $23 \%$ \\
\hline Blue-Green Infrastructure & 3 & $3 \%$ \\
\hline Green Infrastructure & 20 & $20 \%$ \\
\hline Urban Green Infrastructure & 1 & $1 \%$ \\
\hline Restoration & 21 & $21 \%$ \\
\hline Ecological Restoration & 2 & $2 \%$ \\
\hline Ecosystem Restoration & 1 & $1 \%$ \\
\hline Ecosystem Services Restoration & 1 & $1 \%$ \\
\hline Restoration & 2 & $2 \%$ \\
\hline River Restoration & 14 & $14 \%$ \\
\hline Stream Restoration & 1 & $1 \%$ \\
\hline Nature-based solution & 14 & $30 \%$ \\
\hline Etc. & 9 & $9 \%$ \\
\hline Conservation & 1 & $1 \%$ \\
\hline Flood Control Infrastructure & 1 & $1 \%$ \\
\hline Hybrid Engineering & 2 & $2 \%$ \\
\hline Integrated Catchment Management & 1 & $1 \%$ \\
\hline Multi-functional Urban Watercourses & 1 & $1 \%$ \\
\hline Planned Retreat & 1 & $1 \%$ \\
\hline River Corridor Management & 1 & $1 \%$ \\
\hline River Engineering, de-culverting & 1 & $1 \%$ \\
\hline Natural Infrastructure & 3 & $3 \%$ \\
\hline Natural and Nature-based Infrastructure & 1 & $1 \%$ \\
\hline Natural Infrastructure & 1 & $1 \%$ \\
\hline Nature-based Infrastructure & 1 & $1 \%$ \\
\hline Total & 102 & $100 \%$ \\
\hline
\end{tabular}

Our analysis revealed that the term 'restoration' was gradually substituted by other emerging terms such as NBS, 'ecosystem-based' and 'green infrastructure' (Figure 3). 


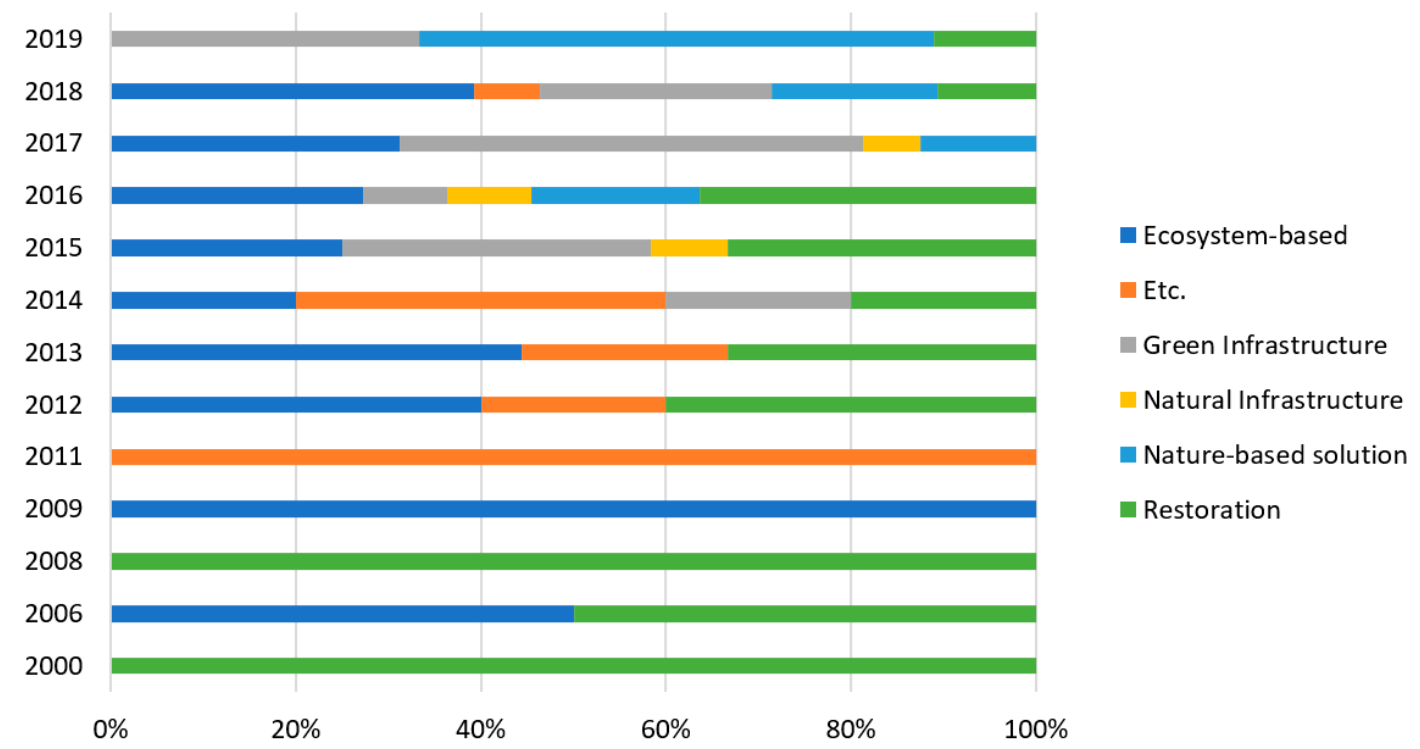

Figure 3. Use of the dominant terms in each paper by publication year.

With 34 papers, most studies were conducted in the European context (32\%), followed by 19 papers in North America (18\%) and 13 in Asia constituting 12\% (Table 4).

Table 4. Number of papers by continent.

\begin{tabular}{ccc}
\hline Continent & \# of Papers & Percent \\
\hline Europe & 34 & $32 \%$ \\
North America & 19 & $18 \%$ \\
Asia & 13 & $12 \%$ \\
Africa & 4 & $4 \%$ \\
South America & 4 & $4 \%$ \\
Oceania & 3 & $3 \%$ \\
Global & 28 & $27 \%$ \\
\hline Total & $105^{1}$ & $100 \%$
\end{tabular}

${ }^{1}$ When the research was conducted at more than one site, all sites were counted. Therefore, total number of papers did not conform to the total number of reviewed papers $(N=102)$.

Within the sample of this study, studies pursuing an 'ecosystem-based' approach were most frequent in Asia. The terms 'NBS' and 'green infrastructure' were most commonly applied in Europe and in North America (particularly in the US) the term 'restoration' was used most often. Interestingly, 'green infrastructure' was used relatively evenly among all three continents (Figure 4). 


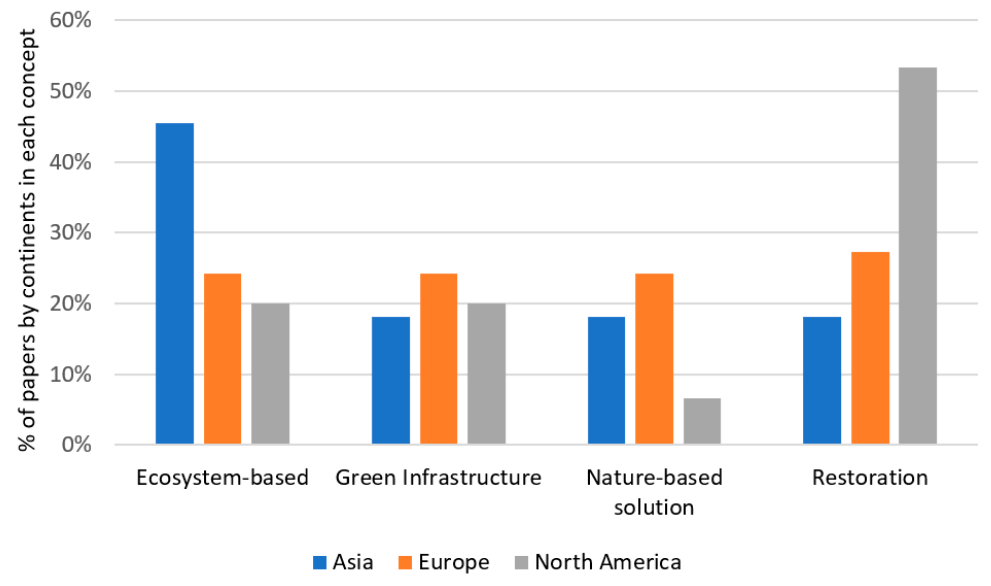

Figure 4. Use of the terms by three major continents.

\subsection{Core Topics}

There are six core topics with respect to perceptions of NBS as a means to reduce hydro-meteorological risks we could identify by scanning 102 relevant papers: (1) valuation of co-benefits (including the valuation of benefits related to ecosystems and society), (2) evaluation of risk reduction efficacy, (3) stakeholder participation, (4) socio-economic and location-specific conditions, (5) environmental attitude, and (6) uncertainty. Table 5 provides an overview of the key features that are dealt with in the single topics.

Table 5. Core topics for perceptions of NBS.

\begin{tabular}{lc}
\hline \multicolumn{1}{c}{ Topics } & Key References \\
\hline (1) Valuation of co-benefits & {$[30,67-70]$} \\
- Valuation of benefits for ecosystem & {$[20,30,31,71-75]$} \\
- Valuation of societal or other benefits & \\
(2) Evaluation of risk reduction efficacy & \\
- Relevance of the physical presence and visibility of measures & {$[20,30,31,72,73,76-78]$} \\
- Expectation towards the successful realization of NBS & {$[30,71,79]$} \\
(3) Stakeholder participation & \\
- Role of communication between stakeholders & {$[31,71,80-83]$} \\
- Role of trust between stakeholders & {$[84-86]$} \\
- Role of trust in institutions & {$[87]$} \\
(4) Socio-economic and location-specific condition & {$[75,88]$} \\
- Individual economic conditions & {$[33,74,89,90]$} \\
- Educational level & {$[30,91-94]$} \\
- Location-specific conditions & {$[84,88]$} \\
- Environmental justice and equity & \\
(5) Environmental Attitude & {$[74,91,93]$} \\
- Stewardship of nature & {$[21,53,77,95,96]$} \\
(6) Uncertainty & {$[30,53,84,91,94,97-99]$} \\
- Time lag for observing benefits & {$[21,100]$} \\
- Lack of data and knowledge & - Uncertain conditions upon human-nature interactions
\end{tabular}

\subsection{In-Depth Analysis Based on Empirical Evidence for Core Topics}

The in-depth analysis was based on six key topics derived from the scanning process of the 31 field data studies. The investigation process allowed us to grasp what kind of empirical evidences are presented with respect to the six key topics.

The analysis first revealed that 21 out of 31 papers $(68 \%)$ did not show any explicit theories. Three papers used utility theory, along with contingent valuation and choice modeling as a methodology 
to scrutinize people's preferences. Another three papers were based on grounded theory, which is rather a methodological for gathering and analyzing data based inductive reasoning. In addition, we found that the following theories were utilized by one paper each: the theory of sustainability transition, the theory of adaptive co-management, human ecology and interdisciplinary theories of governance, socio-ecological systems, infrastructure studies, and multilevel politics. Last, we identified some papers that, while not explicitly engaged with a theory, showed a slight inclination towards certain theories such as protection motivation theory and environmental justice. In the following subsections, we analyzed how empirical studies illustrate and operationalize six key topics and the underlying relationships between the constructs.

\subsubsection{Valuation of Co-Benefits}

One of the most prominent topics in the reviewed literature, represented in 15 papers, addresses how people value and perceive the co-benefits of NBS and related concepts. The assessment, evaluation and demonstration of the wider benefits of NBS is currently a prominent topic in research on NBS and emphasizes the funding of Horizon 2020 calls [101]. Compared to conventional, technical, and/or engineering-based solutions, NBS are expected to deliver wider benefits, including various 'ecosystem services' they provide to society [85]. Therefore, studies have explored how people value ecosystem services and how this influences their perceptions of NBS. All reviewed studies are based on surveys, interviews and workshops. The following methods were adopted: content analysis [30,102], statistical analysis [74,103], contingent valuation as a form of willingness to pay [85], and multi-criteria decision analysis (MCDA) paired with multi-attribute utility theory and choice experiment [67].

Studies focusing on the individual valuation of co-benefits focused predominantly on aesthetical $[20,31,87,102,104]$ and recreational aspects $[30,71,87,105]$. Both co-benefits seem to have a positive influence on people's perception of NBS, although in some studies aesthetical aspects were found to be perceived as of lower relevance compared to other co-benefits [31,104].

Other studies explored attitudes towards NBS compared to more established technical-engineering based measures to reduce risks. Findings indicate that people support NBS and that they prefer NBS if they also positively value wider social and natural co-benefits, such as aesthetical, recreational, economic, and nature-related aspects $[31,103,106]$.

Studies have also explored how interaction with NBS shape individual perceptions of NBS. People who directly interact with NBS report higher awareness of both the potential positive effects of NBS and of risks compared to people with lower degrees of interaction, such as tourists [74], users compared to non-users [75], or NBS sites that are less accessible [71].

\subsubsection{Evaluation of Risk Reduction Efficacy}

The perceived efficacy of NBS is another prominent topic in the literature we reviewed $(n=9)$. As NBS are often replacing or complementing more established technical, engineering-based risk reduction measures, many studies take a comparative perspective by, at least implicitly, comparing the efficacy of established measures with NBS.

NBS and related approaches are often perceived by people as being less effective than traditional protection schemes. This pattern was found in the management of coastal hazards [30] and urban flooding (e.g., removal of culverts) $[79,102,105,106]$. We can only speculate about the reasons for this pattern: Some authors suggest that the immediate physical presence and visibility of technical measures are interpreted by individuals as a demonstration of progress and problem-solving attitudes by responsible governmental bodies [32], and may also contribute to an increased feeling of protection $[30,106]$. Other studies point to the underlying threat appraisal. People who perceive a high threat of future typhoons and monsoon events also report higher trust in technical solutions than in NBS [79]. Similarly, the ambivalent role of pioneering projects is touched upon: if preceding NBS projects were not well planned and implemented and turned out to be ineffective, this can undermine people's trust in their effectiveness [79]. 
We found one study stating that respondents of a survey reported that flood risk was reduced and that this reduction was attributable to the successful realization of NBS [71]. Another study suggested that the framing of NBS as a means to enhance the safety of a place could positively influence the perceived efficacy of NBS [87]. At the same time, one study showed that lower levels of perceived efficacy of NBS do not affect the support of people. Wong-Parodi and Klima [103] found out that people support and prefer green infrastructure over gray, even though they think that current engineer-based infrastructure secures them more effectively.

\subsubsection{Stakeholder Participation}

Stakeholder participation has received attention as one of the essential elements in risk management processes and NBS implementation. It is crucial to respect the right of stakeholders, including those affected by NBS for hydro-meteorological risk reduction purpose, to be involved in decision-making processes and to facilitate effective solutions for societal problems [107].

The willingness of stakeholders to take part in the realization of NBS can be explained in multiple ways, including from a supportive attitude towards NBS, or from strong resistance to the realization of NBS.

Although participation was touched upon in 12 of the empirical studies we reviewed, it was not usually their main focus. Nevertheless, we found several cases that prove that participation can stimulate people to be aware of ongoing local problems and needs $[32,106]$. This can result in improved stakeholder coordination to realize projects [108]. In addition, participation can embrace the diversity of the affected community in the design and planning process, promoting local buy-in of solutions [31]. In this regard, effective communication among stakeholders is considered key to innovation and dynamism in NBS projects [32,71], which can be a driving force to sustainable project implementation [20].

A few other studies insist that trust influences stakeholder participation and involvement. Trust between stakeholders facilitates the exchange of information and strengthen relationships [32]. By doing so, it enhances stakeholder's acceptance of vulnerability to project implementation $[84,86]$ and can ease conflicts of interest between actors [85]. In addition, participation can also increase ownership among local communities of the realization of NBS projects [84]. Furthermore, trust in responsible organizations and institutions (as exemplified in the Room for River Program in the Netherlands and people's trust in Dutch safety standards) brings more support for new solutions [87]. When involved communities have a strong attachment to a proposed project site, extra care for the building of trust is needed [87].

Lastly, the studies also found that wider stakeholder participation can contribute to mainstreaming NBS while fulfilling the project's ecological aim [109]. In order to foster more participation and satisfaction of stakeholders, the implementation scheme, including the purpose and technique of the project, should be described to them in advance of its implementation [110]. Likewise, a realistic implementation scheme, including information about long-term benefits or time lags in a project's successful delivery, should be shared between stakeholders to prevent frustration [71].

\subsubsection{Socio-Economic and Location-Specific Conditions}

Numerous other papers $(n=10)$ have reported socio-economic and location-specific conditions related to people's perceptions of NBS. However, the reviewed papers provided inconsistent findings; they showed heterogeneous results that are largely shaped by the respective context.

In contrast with a study that indicated that different socio-economic conditions do not affect perceptions of green measures [88], other papers show evidence for such a correlation. For example, Sheng et al. [110] found that household income and the amount of government subsidy received for owned pasture area correlated with the positive support of a restoration project. However, Brouwer et al. [75] found that this correlation is not universal but only occurs for lower-income households depending on the respective national context. Furthermore, educational level seems to have a clear 
positive effect on perceptions of NBS [74,111]. This observation can be linked with the finding that a lack of knowledge/understanding of NBS affects people's supportive attitudes [30,89,90].

Other studies found that a preference for NBS can be location-specific $[30,103]$. On the one hand, the location associated with the personal experiences of a hazard influences perceptions of NBS [30]. This is particularly true for negative experiences, which may impede NBS support [111]. On the other hand, socio-cultural aspects seem to influence the preference of the local communities with respect to NBS. In detail, it can differ depending on how much people are attached to the project location [87] and the local history regarding mitigation measures [30].

\subsubsection{Environmental Attitude}

A few studies $(n=2)$ have found evidence that the environmental attitude of stakeholders shapes their attitude towards NBS. For instance, people who reported higher degrees of stewardship to nature or, otherwise stated, those who put a higher value on feeling responsible for the conservation of nature, preferred NBS over more conventional flood management approaches [93]. Another study interpreted a preference for NBS as evidence of altruistic behavior: though individuals did not receive any personal benefit, they still preferred NBS for the sake of 'the level of environmental quality provided' and 'the act of giving' [67].

\subsubsection{Uncertainty}

A considerable number of papers, which we scanned previously for the core topics, mentioned uncertainty in NBS implementation. This was attributed to lack of long-term data and the complexity inherent in nature (i.e., 'surprise', given by the variability of nature as a baseline) and human-nature interactions, which depend on physical, ecological, and socio-economic conditions (see Table 5). However, these arguments are backed up by merely two empirical studies. First, uncertain aspects of project implementation are seen to play a role in raising local concerns about safety. It relates to the individual perception of risk efficacy of NBS, and the idea that unstable features of nature threaten local people [105]. Second, a survey-based study revealed that a lack of knowledge and understanding was a barrier to gaining support from local authorities and public [89].

\section{Discussion}

This review has thematically focused on documenting state-of-the-art factors that shape perceptions of NBS by means of reducing hydro-meteorological risks. Departing from a rather broad understanding of NBS that is grounded in the definitions of NBS provided by the EC and IUCN, we also included neighboring terms in this review to ensure broad thematic coverage.

Based on 102 studies, we identified six topics shaping the current discussion in this field of research. The empirical insights concerning these topics are not only diverse but also sometimes even contradictory, and they also vary in the depth of the insights generated. Most pronounced are studies focusing on affected people's perceptions of the co-benefits and efficacy of NBS.

Concerning perceptions of co-benefits, the results are relatively consistent: Studies suggest that if co-benefits are valued positively, NBS are also perceived positively, particularly if people have direct access to NBS and interact with these solutions relatively often. However, the studies we reviewed focused only on co-benefits related to recreational and aesthetical aspects of NBS - other aspects such as health, wellbeing, cultural values, and economic development have not yet been considered.

As for the perceived efficacy of NBS, findings are rather mixed. While NBS are often perceived as less effective than more established and technical risk reduction measures, we know very little about the underlying reasons for this tendency. Next to the immediate physical presence of technical measures, the relation between perceived efficacy of NBS and threat appraisal seems relevant: if threat appraisal is high, trust in NBS seems to be lower. However, few available studies explore this connection more thoroughly. Some studies indicate that trust in NBS efficacy can increase over time if exposed residents realize that NBS can reduce the risk of hydro-meteorological events. 
Regarding socio-economic and location-specific conditions, findings are also mixed: While some studies suggest no correlation between socio-economic statuses of households and their perception of NBS, other studies highlight a correlation. We assume that contextual factors play a decisive role here. This is at least suggested by the cross-country studies conducted by Brouwer et al. [75], which imply that different spatial, socio-economic-demographic, cultural, and institutional settings may correlate with a different perception of NBS.

Very few studies have focused on how people's environmental attitudes shape their perceptions of NBS. It was shown that people who report higher degrees of stewardship to nature prefer NBS over more conventional flood management approaches $[67,93]$.

The role of uncertainty is also seldom explored. High uncertainty concerning the realization of NBS projects may undermine people's feelings of safety, furthermore, a lack of knowledge about the effects of NBS may also be a barrier for the support for NBS.

Finally, findings on stakeholder participation are rather limited. We found that participation can stimulate people's awareness of ongoing local problems and needs, and can, therefore, result in improved stakeholder coordination to realize projects. Stakeholder perceptions of NBS also seem to be positively influenced when effectively informed about the realization of NBS. Studies also found that wider stakeholder participation can contribute to the mainstreaming of NBS and can help fulfill the wider ecological objectives of NBS projects.

The field of research in this review is still emerging. Among the papers we reviewed, very few focus explicitly on NBS to reduce hydro-meteorological risks and how they are perceived. The majority focuses on other topics, though they do touch upon the core topics of this paper. The studies we identified as most relevant for this paper (i.e., defined by an explicated methodology aiming at generating evidence) also underline that this research field is still developing. Most of the papers did not explicate their underlying theories. This hampers the comparability of empirical insights. For instance, in other related fields of research (e.g., what motivates individual adaptive behavior) where at least basic theoretical aspects are shared (e.g., protection motivation theory), a comparison of empirical studies has become possible eventually by allowing the conduction of statistically grounded meta-analyses [112]. However, this is barely possible in for the reviewed studies, most of which collect empirical data and insights without grounding them in a theoretical framework.

As an implication of the previously identified gap, there are hardly any studies that systematically frame the inter-linkages between the different constructs we previously outlined. Based on the review, however, it is possible to outline some basal inter-linkages that require further exploration in future studies (see Figure 5). We also believe that this generic model has the potential to be applied in other hazard contexts such as a landslide and earthquake, which can be investigated more in-depth in future studies.

More specifically, we expect that interacting constructs, particularly the valuation of efficacy and co-benefits of NBS, could influence people's perception of NBS. We also consider it likely that other variables might moderate these interactions. First, people's threat appraisal could moderate the impact of evaluation of risk reduction efficacy on perceptions of NBS. If people feel threatened by the consequences of hydro-meteorological risks, they may have lower levels of trust in the effectiveness of NBS to reduce risk. This lack of trust could outweigh positive attitudes towards the co-benefits of NBS, and result in negative attitudes towards NBS. However, it is likely that people's threat appraisal not only relates to primary hydro-meteorological risks but also to potential secondary risks related to NBS. People may believe that the replacement of technical measures with NBS will increase hydro-meteorological risk for their property [113], or that NBS may cause new risks such as invasive organic species or rising groundwater levels [54]. Second, we also expect that people's environmental attitudes and the likelihood of their direct use of, or interaction with, NBS could moderate their perception of co-benefits. If people have a strong pro-environmental attitude, this might positively reinforce the impact of their valuation of the NBS co-benefits. Perceived NBS co-benefits also might then outweigh concern about the efficacy of NBS, resulting in more positive attitudes towards NBS. 
Likewise, if affected people are more likely to benefit from or interact with NBS due to spatial proximity, etc., this might positively moderate the valuation of co-benefits. However, at this stage, we can only speculate about these construct interactions.

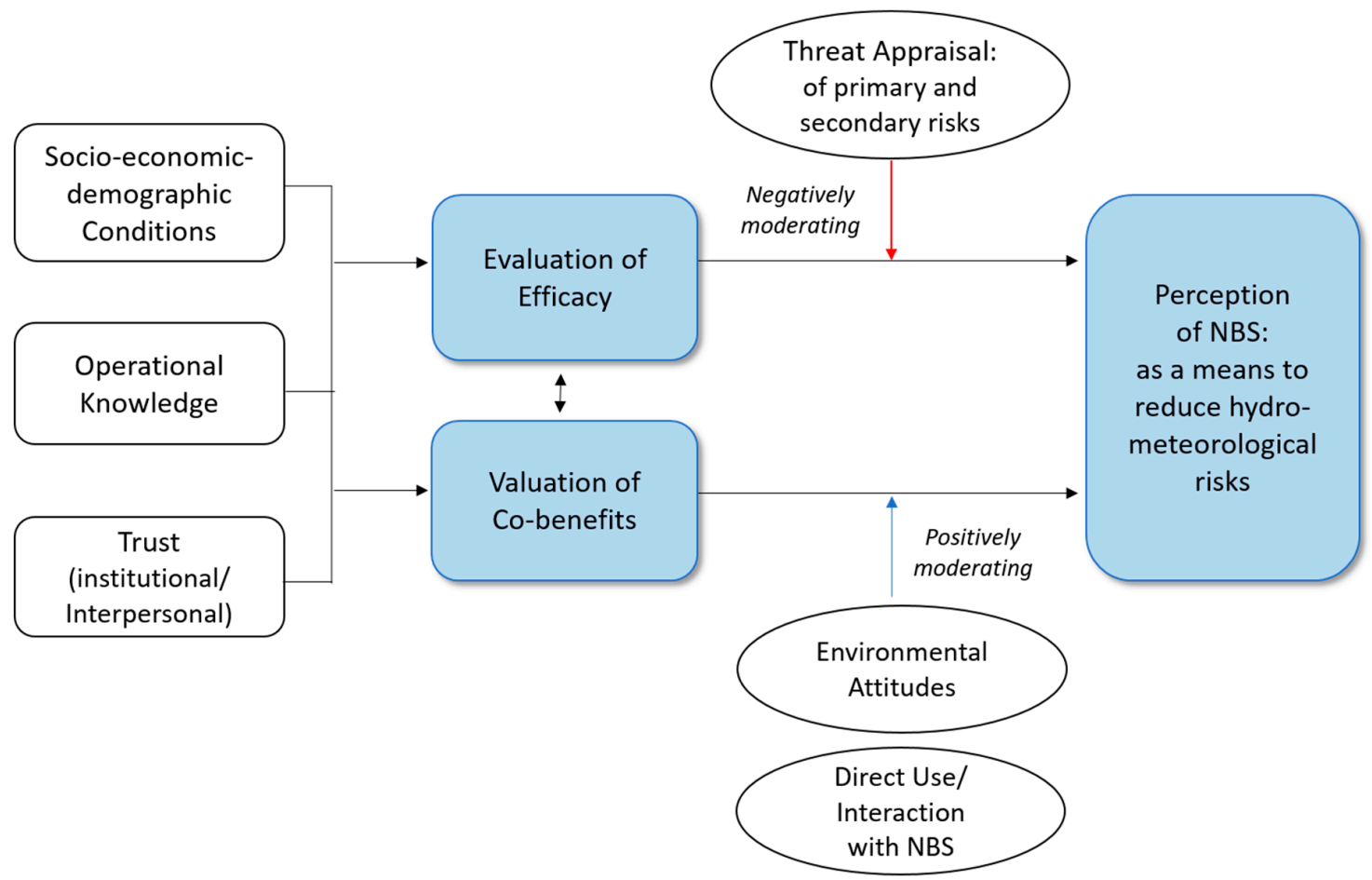

Figure 5. A generic model for the potential interplay of key constructs underlying perceptions of NBS as a means to reduce hydro-meteorological risks.

Furthermore, we assume that an individual's valuation of NBS co-benefits and efficacy might be influenced by their socio-economic-demographic conditions and NBS knowledge (for instance, knowledge about the effects of NBS and realistic implementation scheme), possibly obtained from prior experiences or other informational sources. Based on our literature review, we could only conjecture about the role of people's socio-economic-demographic situation and point towards contextual factors. In addition, it is assumed that both intrapersonal (i.e., between stakeholders) and institutional (i.e., in responsible organizations and institutions) trust shape the valuation of NBS co-benefits and efficacy. We also surmise that participation may play a role in stimulating these factors and, ultimately, positively influence the valuation of efficacy and co-benefits.

While we believe that a more structured and theoretically grounded approach to the assessment of people's perception of NBS is necessary, we also consider that greater attention needs to be paid to what counts as NBS. In this study, we reviewed a considerable number of publications that focused on different concepts, such as ecosystem-based adaptation, restoration, and green infrastructure. As the concept of NBS implies, at least in its more inclusive definition, all 'solutions' are comparable as long as they are directed towards addressing societal challenges, provide co-benefits and are inspired or supported by ecosystems. Focusing on how people perceive NBS, however, it is debatable that a small-scale hybrid NBS, implemented in an urban context, is comparable to a large-scale river restoration project at the catchment scale, the latter of which not only influences people's livelihoods but also profoundly transforms an entire landscape. In addition, environmental attitudes were distinctively scrutinized in publications focusing on restoration, while the perceived co-benefit was explored more systematically in literature dealing with NBS and green infrastructure literature. Such differences, both for NBS and thematic emphases, need to be accounted for more carefully in future research. 
We, therefore, propose that future research should reflect these different NBS by using a more conscious sampling strategy, at least for the quantitative standardized surveys-this would contribute a better understanding of how different NBS perceptions are shaped. The typology proposed by Eggermont et al. [54] can offer some instructive insights on how to operationalize such a sampling procedure. They argue that NBS approaches can be broadly classified into three types along a gradient of the level and intensity of engineering applied. Type 1 NBS approaches involve no or minimal intervention in ecosystems, type 2 measures are aimed at establishing sustainable and multifunctional ecosystems, and type 3 NBS approaches imply a profound transformation of ecosystems possibly even resulting in new ecosystems. Based on our review, we assume that these fundamental differences in NBS setup would have a great impact on people's attitudes towards them. Therefore, such differences should be reflected in the selection of case studies for empirical research.

\section{Conclusions}

We believe that more social science research, based on rigorous methodologies and grounded in social science theories, is needed to complement the currently dominant approach that focuses on the quantitative evaluation of NBS co-benefits. As this review has indicated, our knowledge about perceptions of NBS as a means to reduce hydro-meteorological risks is still hampered by profound gaps in knowledge. With this article, we have outlined some avenues for future research.

Our results show that the current knowledge of concepts surrounding perceptions of NBS is not always consistent. While perceived co-benefits show a relatively strong positive impact on the people's perceptions of NBS, other factors such as perceived efficacy of NBS and individual socio-economic-demographic conditions show conflicting results. We concluded that the scale of each NBS project (e.g., large-scale river restoration compared with small scale installation of green infrastructure) and the level of engineering used can contribute to the discrepancies in perceptions of NBS shown in the empirical studies. Therefore, we propose that future empirical studies regarding perceptions of NBS should conduct a careful sampling of different NBS and be cognizant of comparing NBS projects. We also found that some essential variables, such as environmental attitudes and uncertainty, have been overlooked in the empirical research. Finally, our model for the potential interplay of key constructs underlying perceptions of NBS shows the possible relationships between constructs and emphasizes the need for a theoretical framework. Such frameworks encompass fragmented knowledge and generate meaningful insights to help raise people's supportive attitudes towards NBS.

Author Contributions: Conceptualization, S.H. and C.K.; methodology, S.H. and C.K.; validation, S.H. and C.K.; investigation, S.H. and C.K.; writing-original draft preparation, S.H.; writing-review and editing, C.K.; visualization, S.H.; supervision, C.K.

Funding: C.K. received funding from the European Union's Horizon 2020 research and innovation program under grant agreement No. 776866.

Acknowledgments: S.H. would like to express her gratitude for the research support from German Academic Exchange Service (DAAD).

Conflicts of Interest: The authors declare no conflict of interest.

\section{References}

1. Wu, H.; Huang, M.; Tang, Q.; Kirschbaum, D.B.; Ward, P. Hydrometeorological hazards: Monitoring, forecasting, risk assessment, and socioeconomic responses. Adv. Meteorol. 2016, 3. [CrossRef]

2. Blaikie, P.; Cannon, T.; Davis, I.; Wisner, B. At Risk: Natural Hazards, People's Vulnerability, and Disaster; Routledge: London, UK; New York, NY, USA, 1994.

3. Watts, M.J.; Bohle, H.G. The space of vulnerability: The causal structure of hunger and famine. Prog. Hum. Geogr. 1993, 17, 43-67. [CrossRef]

4. Kundzewicz, Z.W.; Jania, J.A. Extreme hydro-meteorological events and their impacts. From the global down to the regional scale. Geogr. Pol. 2007, 80, 9-23. 
5. Hirabayashi, Y.; Mahendran, R.; Koirala, S.; Konoshima, L.; Yamazaki, D.; Watanabe, S.; Kim, H.; Kanae, S. Global flood risk under climate change. Nat. Clim. Chang. 2013, 3, 816. [CrossRef]

6. Milly, P.C.D.; Betancourt, J.; Falkenmark, M.; Hirsch, R.M.; Kundzewicz, Z.W.; Lettenmaier, D.P.; Stouffer, R.J. Stationarity is dead: Whither water management? Science 2008, 319, 573-574. [CrossRef] [PubMed]

7. Thieken, A.H.; Cammerer, H.; Dobler, C.; Lammel, J.; Schöberl, F. Estimating changes in flood risks and benefits of non-structural adaptation strategies-A case study from Tyrol, Austria. Mitig. Adapt. Strateg. Glob. Chang. 2016, 21, 343-376. [CrossRef]

8. Field, C.B.; Barros, V.; Stocker, T.F.; Dahe, Q. Managing the Risks of Extreme Events and Disasters to Advance Climate Change Adaptation: Special Report of the Intergovernmental Panel on Climate Change; Cambridge University Press: Cambridge, UK, 2012.

9. Hooijer, A.; Klijn, F.; Pedroli, G.B.M.; Van Os, A.G. Towards sustainable flood risk management in the Rhine and Meuse river basins: Synopsis of the findings of IRMA-SPONGE. River Res. Appl. 2004, 20, 343-357. [CrossRef]

10. Rogger, M.; Agnoletti, M.; Alaoui, A.; Bathurst, J.C.; Bodner, G.; Borga, M.; Chaplot, V.; Gallart, F.; Glatzel, G.; Hall, J.; et al. Land use change impacts on floods at the catchment scale: Challenges and opportunities for future research. Water Resour. Res. 2017, 53, 5209-5219. [CrossRef]

11. Seto, K.C.; Fragkias, M.; Güneralp, B.; Reilly, M.K.J.P.O. A meta-analysis of global urban land expansion. PLoS One 2011, 6, e23777. [CrossRef]

12. Beckers, A.; Dewals, B.; Erpicum, S.; Dujardin, S.; Detrembleur, S.; Teller, J.; Pirotton, M.; Archambeau, P. Contribution of land use changes to future flood damage along the river Meuse in the Walloon region. Nat. Hazards Earth Syst. Sci. 2013, 13, 2301-2318. [CrossRef]

13. Hall, J.W.; Sayers, P.B.; Walkden, M.J.; Panzeri, M. Impacts of climate change on coastal flood risk in England and Wales: 2030-2100. Philos. Trans. R. Soc. A Math. Phys. Eng. Sci. 2006, 364, 1027-1049. [CrossRef] [PubMed]

14. Barredo, J.I. Normalised flood losses in Europe: 1970-2006. Nat. Hazards Earth Syst. Sci. 2009, 9, 97-104. [CrossRef]

15. Accastello, C.; Blanc, S.; Brun, F. A framework for the integration of nature-based solutions into environmental risk management strategies. Sustainability 2019, 11, 489. [CrossRef]

16. Kabisch, N.; Korn, H.; Stadler, J.; Bonn, A. (Eds.) Nature-Based Solutions to Climate Change Adaptation in Urban Areas: Linkages between Science, Policy and Practice; Springer: Cham, Switzerland, 2017.

17. Bubeck, P.; Kreibich, H.; Penning-Rowsell, E.C.; Botzen, W.J.W.; de Moel, H.; Klijn, F. Explaining differences in flood management approaches in Europe and in the USA-A comparative analysis. J. Flood Risk Manag. 2017, 10, 436-445. [CrossRef]

18. Mitsch, W.J.; Jørgensen, S.E. Ecological engineering: A field whose time has come. Ecol. Eng. 2003, 20 , 363-377. [CrossRef]

19. Fernandes, J.P.A.; Guiomar, N. Environmental ethics: Driving factors beneath behavior, discourse and decision-making. J. Agric. Environ. Ethics 2016, 29, 507-540. [CrossRef]

20. Barthelemy, C.; Armani, G. A comparison of social processes at three sites of the French Rhone River subjected to ecological restoration. Freshw. Biol. 2015, 60, 1208-1220. [CrossRef]

21. Doswald, N.; Munroe, R.; Roe, D.; Giuliani, A.; Castelli, I.; Stephens, J.; Moller, I.; Spencer, T.; Vira, B.; Reid, H. Effectiveness of ecosystem-based approaches for adaptation: Review of the evidence-base. Clim. Dev. 2014, 6, 185-201. [CrossRef]

22. Collentine, D.; Futter, M.N. Realising the potential of natural water retention measures in catchment flood management: Trade-offs and matching interests. J. Flood Risk Manag. 2018, 11, 76-84. [CrossRef]

23. Nesshover, C.; Assmuth, T.; Irvine, K.N.; Rusch, G.M.; Waylen, K.A.; Delbaere, B.; Haase, D.; Jones-Walters, L.; Keune, H.; Kovacs, E.; et al. The science, policy and practice of nature-based solutions: An interdisciplinary perspective. Sci. Total Environ. 2017, 579, 1215-1227. [CrossRef]

24. Raymond, C.M.; Frantzeskaki, N.; Kabisch, N.; Berry, P.; Breil, M.; Nita, M.R.; Geneletti, D.; Calfapietra, C. A framework for assessing and implementing the co-benefits of nature-based solutions in urban areas. Environ. Sci. Policy 2017, 77, 15-24. [CrossRef]

25. Albert, C.; Schroter, B.; Haase, D.; Brillinger, M.; Henze, J.; Herrmann, S.; Gottwald, S.; Guerrero, P.; Nicolas, C.; Matzdorf, B. Addressing societal challenges through nature-based solutions: How can landscape planning and governance research contribute? Landsc. Urban Plan. 2019, 182, 12-21. [CrossRef] 
26. Brink, E.; Aalders, T.; Adam, D.; Feller, R.; Henselek, Y.; Hoffmann, A.; Ibe, K.; Matthey-Doret, A.; Meyer, M.; Negrut, N.L.; et al. Cascades of green: A review of ecosystem-based adaptation in urban areas. Glob. Environ. Chang. 2016, 36, 111-123. [CrossRef]

27. van Wesenbeeck, B.; IJff, S.; Jongman, B.; Balog, S.; Kaupa, S.; Bosche, L.; Lange, G.; Holm-Nielsen, N.; Nieboer, H.; Taishi, Y. Implementing nature based flood protection: principles and implementation guidance (English); World Bank Group: Washington, DC, USA, 2017.

28. Kabisch, N.; Frantzeskaki, N.; Pauleit, S.; Naumann, S.; Davis, M.; Artmann, M.; Haase, D.; Knapp, S.; Korn, H.; Stadler, J.; et al. Nature-based solutions to climate change mitigation and adaptation in urban areas: Perspectives on indicators, knowledge gaps, barriers, and opportunities for action. Ecol. Soc. 2016, 21, 39. [CrossRef]

29. Dhakal, K.P.; Chevalier, L.R. Managing urban stormwater for urban sustainability: Barriers and policy solutions for green infrastructure application. J. Environ. Manag. 2017, 203, 171-181. [CrossRef] [PubMed]

30. Gray, J.D.E.; O'Neill, K.; Qiu, Z.Y. Coastal residents' perceptions of the function of and relationship between engineered and natural infrastructure for coastal hazard mitigation. Ocean Coast. Manag. 2017, 146, $144-156$. [CrossRef]

31. Loos, J.R.; Rogers, S.H. Understanding stakeholder preferences for flood adaptation alternatives with natural capital implications. Ecol. Soc. 2016, 21. [CrossRef]

32. Ardaya, A.B.; Evers, M.; Ribbe, L. What influences disaster risk perception? Intervention measures, flood and landslide risk perception of the population living in flood risk areas in Rio de Janeiro state, Brazil. Int. J. Disaster Risk Reduct. 2017, 25, 227-237. [CrossRef]

33. Short, C.; Clarke, L.; Carnelli, F.; Uttley, C.; Smith, B. Capturing the multiple benefits associated with nature-based solutions: Lessons from a natural flood management project in the Cotswolds, UK. Land Degrad. Dev. 2019, 30, 241-252. [CrossRef]

34. Slovic, P. Perception of risk. Science 1987, 236, 280-285. [CrossRef]

35. Renn, O. Concepts of risk: A classification. In Social Theories of Risk; Krimsky, S., Golding, D., Eds.; Praeger: Westport, CT, USA; London, UK, 1992; pp. 53-79.

36. Renn, O. Three decades of risk research: Accomplishments and new challenges. J. Risk Res. 1998, 1, 49-71. [CrossRef]

37. Wachinger, G.; Renn, O.; Begg, C.; Kuhlicke, C. The risk perception paradox-implications for governance and communication of natural hazards. Risk Anal. 2013, 33, 1049-1065. [CrossRef] [PubMed]

38. Grothmann, T.; Reusswig, F. People at risk of flooding: Why some residents take precautionary action while others do not. Nat. Hazards 2006, 38, 101-120. [CrossRef]

39. Zaalberg, R.; Midden, C.; Meijnders, A.; McCalley, T. Prevention, adaptation, and threat denial: Flooding experiences in The Netherlands. Risk Anal. 2009, 29, 1759-1778. [CrossRef] [PubMed]

40. Harvatt, J.; Petts, J.; Chilvers, J. Understanding householder responses to natural hazards: Flooding and sea-level rise comparisons. J. Risk Res. 2011, 14, 63-83. [CrossRef]

41. Terpstra, T.; Lindell, M.K. Citizens' perceptions of flood hazard adjustments: An application of the protective action decision model. Environ. Behav. 2013, 45, 993-1018. [CrossRef]

42. Harries, T. The anticipated emotional consequences of adaptive behaviour-Impacts on the take-up of household flood-protection measures. Environ. Plan. A Econ. Space 2012, 44, 649-668. [CrossRef]

43. Terpstra, T. Emotions, trust, and perceived risk: Affective and cognitive routes to flood preparedness behavior. Risk Anal. 2011, 31, 1658-1675. [CrossRef]

44. Lo, A.Y. The role of social norms in climate adaptation: Mediating risk perception and flood insurance purchase. Glob. Environ. Chang. 2013, 23, 1249-1257. [CrossRef]

45. Poussin, J.K.; Botzen, W.J.W.; Aerts, J.C.J.H. Factors of Influence on flood damage mitigation behavior by households. Environ. Sci. Policy 2014, 40, 69-77. [CrossRef]

46. Kim, Y.-C.; Kang, J. Communication, neighbourhood belonging and household hurricane preparedness. Disasters 2010, 34, 470-488. [CrossRef] [PubMed]

47. Albert, C.; Spangenberg, J.H.; Schröter, B. Nature-based solutions: Criteria. Nature 2017, 543, 315. [CrossRef] [PubMed] 
48. Pauleit, S.; Zölch, T.; Hansen, R.; Randrup, T.B.; Konijnendijk van den Bosch, C. Nature-based solutions and climate change-Four shades of green. In Nature-Based Solutions to Climate Change Adaptation in Urban Areas: Linkages between Science, Policy and Practice; Kabisch, N., Korn, H., Stadler, J., Bonn, A., Eds.; Springer International Publishing: Cham, Switzerland, 2017; pp. 29-49. [CrossRef]

49. Faivre, N.; Fritz, M.; Freitas, T.; de Boissezon, B.; Vandewoestijne, S. Nature-Based Solutions in the EU: Innovating with nature to address social, economic and environmental challenges. Environ. Res. 2017, 159, 509-518. [CrossRef] [PubMed]

50. Cohen-Shacham, E.; Walters, G.; Janzen, C.; Maginnis, S.J.I. Nature-Based Solutions to Address Global Societal Challenges; IUCN: Gland, Switzerland, 2016; Volume 97.

51. Fernandes, J.P.; Guiomar, N. Nature-based solutions: The need to increase the knowledge on their potentialities and limits. Land Degrad. Dev. 2018, 29, 1925-1939. [CrossRef]

52. Kronenberg, J.; Bergier, T.; Maliszewska, K. The challenge of innovation diffusion: Nature-based solutions in Poland. In Nature-Based Solutions to Climate Change Adaptation in Urban Areas; Springer: Cham, Switzerland, 2017; pp. 291-305.

53. Spalding, M.D.; McIvor, A.L.; Beck, M.W.; Koch, E.W.; Moller, I.; Reed, D.J.; Rubinoff, P.; Spencer, T.; Tolhurst, T.J.; Wamsley, T.V.; et al. Coastal ecosystems: A critical element of risk reduction. Conserv. Lett. 2013, 7, 293-301. [CrossRef]

54. Eggermont, H.; Balian, E.; Azevedo, J.M.N.; Beumer, V.; Brodin, T.; Claudet, J.; Fady, B.; Grube, M.; Keune, H.; Lamarque, P.; et al. Nature-based solutions: New influence for environmental management and research in Europe. GAIA 2015, 24, 243-248. [CrossRef]

55. Palmer, M.A.; Hondula, K.L.; Koch, B.J. Ecological restoration of streams and rivers: Shifting strategies and shifting goals. Annu. Rev. Ecol. Evol. Syst. 2014, 45, 247-269. [CrossRef]

56. European Commission. Green Infrastructure (Gi)_Enhancing Europe's Natural Capital; European Commission: Brussels, Belgium, 2013.

57. Convention on Biological Diversity. Connecting Biodiversity and Climate Change Mitigation and Adaptation: Key Messages from the Report of the Second Ad Hoc Technical Expert Group on Biodiversity and Climate Chang; Secretariat of the Convention on Biological Diversity: Montreal, QC, Canada, 2009.

58. Addy, S.; Cooksley, S.; Dodd, N.; Waylen, K.; Stockan, J.; Byg, A.; Holstead, K. River Restoration and Biodiversity; IUCN: Gland, Switzerland, 2016.

59. Mitsch, W.J.; Jørgensen, S.E. Ecological Engineering: An Introduction to Ecotechnology; John Wiley\&Sons, Inc.: New York, NY, USA, 1989.

60. Rey, F.; Cécillon, L.; Cordonnier, T.; Jaunatre, R.; Loucougaray, G. Integrating ecological engineering and ecological intensification from management practices to ecosystem services into a generic framework: A review. Agron. Sustain. Dev. 2015, 35, 1335-1345. [CrossRef]

61. Benedict, M.A.; McMahon, E.T. Green Infrastructure: Linking Landscapes and Communities; Island Press: Washington, DC, USA, 2012.

62. Fath, B.D. Encyclopedia of Ecology; Elsevier: Amsterdam, The Netherlands, 2018.

63. Agency, E.E. Green Infrastructure and Territorial Cohesion: The Concept of Green Infrastructure and Its Integration into Policies Using Monitoring Systems; Publications Office of the European Union: Brussels, Belgium, 2011.

64. Bramer, W.M.; Rethlefsen, M.L.; Kleijnen, J.; Franco, O.H. Optimal database combinations for literature searches in systematic reviews: A prospective exploratory study. Syst. Rev. 2017, 6, 245. [CrossRef]

65. Long, R.D.; Charles, A.; Stephenson, R.L. Key principles of marine ecosystem-based management. Mar. Policy 2015, 57, 53-60. [CrossRef]

66. Mell, I.C. Green infrastructure: Reflections on past, present and future praxis. Landsc. Res. 2017, 42, 135-145. [CrossRef]

67. Drake, B.; Smart, J.C.R.; Termansen, M.; Hubacek, K. Public preferences for production of local and global ecosystem services. Reg. Environ. Chang. 2013, 13, 649-659. [CrossRef]

68. Hammersley, M.A.; Scott, C.; Gimblett, R. Evolving conceptions of the role of large dams in social-ecological resilience. Ecol. Soc. 2018, 23. [CrossRef]

69. Jones, S.; Somper, C. The role of green infrastructure in climate change adaptation in London. Geogr. J. 2014, 180, 191-196. [CrossRef]

70. Cousins, J.J. Remaking stormwater as a resource: Technology, law, and citizenship. Wiley Interdiscip. Rev. Water 2018, 5, e1300. [CrossRef] 
71. Tunstall, S.M.; Penning-Rowsell, E.C.; Tapsell, S.M.; Eden, S.E. River restoration: Public attitudes and expectations. J. Chart. Inst. Water Environ. Manag. 2000, 14, 363-370. [CrossRef]

72. Matthews, T.; Lo, A.Y.; Byrne, J.A. Reconceptualizing green infrastructure for climate change adaptation: Barriers to adoption and drivers for uptake by spatial planners. Landsc. Urban Plan. 2015, 138, 155-163. [CrossRef]

73. Gumiero, B.; Mant, J.; Hein, T.; Elso, J.; Boz, B. Linking the restoration of rivers and riparian zones/wetlands in Europe: Sharing knowledge through case studies. Ecol. Eng. 2013, 56, 36-50. [CrossRef]

74. Duan, J.Y.; Wang, Y.F.; Fan, C.; Xia, B.C.; de Groot, R. Perception of urban environmental risks and the effects of urban green infrastructures (UGIs) on human well-being in four public green spaces of Guangzhou, China. Environ. Manag. 2018, 62, 500-517. [CrossRef]

75. Brouwer, R.; Bliem, M.; Getzner, M.; Kerekes, S.; Milton, S.; Palarie, T.; Szerenyi, Z.; Vadineanue, A.; Wagtendonk, A. Valuation and transferability of the non-market benefits of river restoration in the Danube river basin using a choice experiment. Ecol. Eng. 2016, 87, 20-29. [CrossRef]

76. Matthews, J.; Van der Velde, G.; Collas, F.P.L.; De Hoop, L.; Koopman, K.R.; Hendriks, A.J.; Leuven, R. Inconsistencies in the risk classification of alien species and implications for risk assessment in the European Union. Ecosphere 2017, 8, e01832. [CrossRef]

77. Sutton-Grier, A.E.; Wowk, K.; Bamford, H. Future of our coasts: The potential for natural and hybrid infrastructure to enhance the resilience of our coastal communities, economies and ecosystems. Environ. Sci. Policy 2015, 51, 137-148. [CrossRef]

78. Mazzorana, B.; Nardini, A.; Comiti, F.; Vignoli, G.; Cook, E.; Ulloa, H.; Iroume, A. Toward participatory decision-making in river corridor management: Two case studies from the European Alps. J. Environ. Plan. Manag. 2018, 61, 1250-1270. [CrossRef]

79. Chou, R.J. The problems of watercourse redevelopment Disseminating new knowledge about flood risk perception in Taiwan's densely populated, typhoon-affected urban areas. Int. Dev. Plan. Rev. 2012, 34, 241-267. [CrossRef]

80. Brink, E.; Wamsler, C. Collaborative Governance for climate change adaptation: Mapping citizen-municipality interactions. Environ. Policy Gov. 2018, 28, 82-97. [CrossRef]

81. Jones, H.P.; Hole, D.G.; Zavaleta, E.S. Harnessing nature to help people adapt to climate change. Nat. Clim. Chang. 2012, 2, 504. [CrossRef]

82. Biggs, D.; Abel, N.; Knight, A.T.; Leitch, A.; Langston, A.; Ban, N.C. The implementation crisis in conservation planning: Could "mental models" help? Conserv. Lett. 2011, 4, 169-183. [CrossRef]

83. Denjean, B.; Altamirano, M.A.; Graveline, N.; Giordano, R.; van der Keur, P.; Moncoulon, D.; Weinberg, J.; Costa, M.M.; Kozinc, Z.; Mulligan, M.; et al. Natural Assurance Scheme: A level playing field framework for Green-Grey infrastructure development. Environ. Res. 2017, 159, 24-38. [CrossRef]

84. Dalimunthe, S.A. Who manages space? Eco-DRR and the local community. Sustainability 2018, 10, 1705. [CrossRef]

85. Reynaud, A.; Lanzanova, D.; Liquete, C.; Grizzetti, B. Going green? Ex-post valuation of a multipurpose water infrastructure in Northern Italy. Ecosyst. Serv. 2017, 27, 70-81. [CrossRef]

86. Metcalf, E.C.; Mohr, J.J.; Yung, L.; Metcalf, P.; Craig, D. The role of trust in restoration success: Public engagement and temporal and spatial scale in a complex social-ecological system. Restor. Ecol. 2015, 23, 315-324. [CrossRef]

87. Verbrugge, L.; van den Born, R. The role of place attachment in public perceptions of a re-landscaping intervention in the river Waal (The Netherlands). Landsc. Urban Plan. 2018, 177, 241-250. [CrossRef]

88. Ambrey, C.; Byrne, J.; Matthews, T.; Davison, A.; Portanger, C.; Lo, A. Cultivating climate justice: Green infrastructure and suburban disadvantage in Australia. Appl. Geogr. 2017, 89, 52-60. [CrossRef]

89. O'Donnell, E.C.; Lamond, J.E.; Thorne, C.R. Recognising barriers to implementation of Blue-Green Infrastructure: A Newcastle case study. Urban Water J. 2017, 14, 964-971. [CrossRef]

90. Chin, A.; Daniels, M.D.; Urban, M.A.; Piegay, H.; Gregory, K.J.; Bigler, W.; Butt, A.Z.; Grable, J.L.; Gregory, S.V.; Lafrenz, M.; et al. Perceptions of wood in rivers and challenges for stream restoration in the United States. Environ. Manag. 2008, 41, 893-903. [CrossRef]

91. Thorne, C.R.; Lawson, E.C.; Ozawa, C.; Hamlin, S.L.; Smith, L.A. Overcoming uncertainty and barriers to adoption of Blue-Green Infrastructure for urban flood risk management. J. Flood Risk Manag. 2018, 11, S960-S972. [CrossRef] 
92. Laura, M.M.; Adriana, M.K.; Cecilia, B.; La Ludmila, M.; Di Cecilia, P.Y.; Gabriela, P.; Jose, B. Ecological status of a patagonian mountain river: Usefulness of environmental and biotic metrics for rehabilitation assessment. Environ. Manag. 2016, 57, 1166-1187. [CrossRef]

93. de Groot, M. Exploring the relationship between public environmental ethics and river flood policies in western Europe. J. Environ. Manag. 2012, 93, 1-9. [CrossRef]

94. Nalau, J.; Becken, S.; Mackey, B. Ecosystem-based Adaptation: A review of the constraints. Environ. Sci. Policy 2018, 89, 357-364. [CrossRef]

95. McVittie, A.; Cole, L.; Wreford, A.; Sgobbi, A.; Yordi, B. Ecosystem-based solutions for disaster risk reduction: Lessons from European applications of ecosystem-based adaptation measures. Int. J. Disaster Risk Reduct. 2018, 32, 42-54. [CrossRef]

96. Meyer, A. Intertemporal valuation of river restoration. Environ. Resour. Econ. 2013, 54, 41-61. [CrossRef]

97. Carter, J.G.; Handley, J.; Butlin, T.; Gill, S. Adapting cities to climate change-exploring the flood risk management role of green infrastructure landscapes. J. Environ. Plan. Manag. 2017, 61, 1535-1552. [CrossRef]

98. Buhl-Mortensen, L.; Galparsoro, I.; Fernandez, T.V.; Johnson, K.; D’Anna, G.; Badalamenti, F.; Garofalo, G.; Carlstrom, J.; Piwowarczyk, J.; Rabaut, M.; et al. Maritime ecosystem-based management in practice: Lessons learned from the application of a generic spatial planning framework in Europe. Mar. Policy 2017, 75, 174-186. [CrossRef]

99. Triyanti, A.; Chu, E. A survey of governance approaches to ecosystem-based disaster risk reduction: Current gaps and future directions. Int. J. Disaster Risk Reduct. 2018, 32, 11-21. [CrossRef]

100. Liao, K.H. From flood control to flood adaptation: A case study on the Lower Green River Valley and the City of Kent in King County, Washington. Nat. Hazards 2014, 71, 723-750. [CrossRef]

101. Bauduceau, N.; Berry, P.; Cecchi, C.; Elmqvist, T.; Fernandez, M.; Hartig, T.; Krull, W.; Mayerhofer, E.; Sandra, N.; Noring, L. Towards an EU Research and Innovation Policy Agenda for Nature-Based Solutions $\mathcal{E}$ Re-Naturing Cities: Final Report of the Horizon 2020 Expert Group on'Nature-Based Solutions and Re-Naturing Cities'; Publications Office of the European Union: Bruxelles, Belgium, 2015. [CrossRef]

102. Chou, R.J. Exploring the quasi-naturalistic landscaping design of a taiwanese culverted urban stream. Landsc. Res. 2013, 38, 347-367. [CrossRef]

103. Wong-Parodi, G.; Klima, K. Preparing for local adaptation: A study of community understanding and support. Clim. Chang. 2017, 145, 413-429. [CrossRef]

104. Ruiz-Villanueva, V.; Diez-Herrero, A.; Garcia, J.A.; Ollero, A.; Piegay, H.; Stoffel, M. Does the public's negative perception towards wood in rivers relate to recent impact of flooding experiencing? Sci. Total Environ. 2018, 635, 294-307. [CrossRef]

105. Chou, R.J. Achieving successful river restoration in dense urban areas: Lessons from Taiwan. Sustainability 2016, 8, 1159. [CrossRef]

106. Martinez-Juarez, P.; Chiabai, A.; Suarez, C.; Quiroga, S. Insights on urban and periurban adaptation strategies based on stakeholders' perceptions on hard and soft responses to climate change. Sustainability 2019, 11, 647. [CrossRef]

107. van Ham, C.; Klimmek, H. Partnerships for nature-based solutions in urban areas-Showcasing successful examples. In Nature-Based Solutions to Climate Change Adaptation in Urban Areas: Linkages between Science, Policy and Practice; Kabisch, N., Korn, H., Stadler, J., Bonn, A., Eds.; Springer International Publishing: Cham, Switzerland, 2017; pp. 275-289. [CrossRef]

108. Pinto, P.J.; Kondolf, G.M.; Wong, P.L.R. Adapting to sea level rise: Emerging governance issues in the San Francisco Bay Region. Environ. Sci. Policy 2018, 90, 28-37. [CrossRef]

109. Wamsler, C. Mainstreaming ecosystem-based adaptation: Transformation toward sustainability in urban governance and planning. Ecol. Soc. 2015, 20. [CrossRef]

110. Sheng, W.P.; Zhen, L.; Xiao, Y.; Hu, Y.F. Ecological and socioeconomic effects of ecological restoration in Chins's Three Rivers Source Region. Sci. Total Environ. 2019, 650, 2307-2313. [CrossRef] [PubMed]

111. O'Donnell, E.C.; Lamond, J.E.; Thorne, C.R. Learning and Action Alliance framework to facilitate stakeholder collaboration and social learning in urban flood risk management. Environ. Sci. Policy 2018, 80, 1-8. [CrossRef] 
112. Bamberg, S.; Masson, T.; Brewitt, K.; Nemetschek, N. Threat, coping and flood prevention-A meta-analysis. J. Environ. Psychol. 2017, 54, 116-126. [CrossRef]

113. Jørgensen, D.; Renöfält, B. Damned if you do, dammed if you don't: Debates on dam removal in the Swedish media. Ecol. Soc. 2013, 18, 1-9. [CrossRef]

(C) 2019 by the authors. Licensee MDPI, Basel, Switzerland. This article is an open access article distributed under the terms and conditions of the Creative Commons Attribution (CC BY) license (http://creativecommons.org/licenses/by/4.0/). 